\title{
Sprawozdanie z XIX Ogólnopolskiej Konferencji Nnaukowo-Szkoleniowej pt. „Terapia logopedyczna. Metody postępowania w zaburzeniach mowy", Lublin 30 czerwca - 2 lipca 2017 r.
}

W dniach 30 czerwca - 2 lipca odbyła się w Lublinie XIX Ogólnopolska Konferencja Naukowo-Szkoleniowa pt. "Terapia logopedyczna. Metody postępowania w zaburzeniach mowy", połączona z Walnym Zebraniem Członków PTL. Organizatorem konferencji był Zarząd Główny Polskiego Towarzystwa Logopedycznego oraz Zakład Logopedii i Językoznawstwa Stosowanego UMCS w Lublinie.

Patronat honorowy sprawowali: Prezydent Miasta Lublin Krzysztof Żuk, Marszałek Województwa Lubelskiego Sławomir Sosnowski i J.M. Rektor Uniwersytetu im. Marii Curie-Skłodowskiej w Lublinie Prof. dr hab. Stanisław Michałowski. Patronat medialny natomiast przypadł TVP 3 Lublin, Polskiemu Radiu Lublin i Radiu Centrum.

W Komitecie Naukowym konferencji znaleźli się: prof. dr hab. Stanisław Grabias (UMCS), dr hab. prof. UMCS Jolanta Panasiuk (UMCS), dr Katarzyna Kaczorowska-Bray (UG), dr Barbara Kamińska (UG), dr hab. Anita Lorenc (UW), dr Olga Przybyla (UŚ), dr Joanna Stasiak (UMCS), dr hab. prof. UMCS Tomasz Woźniak (UMCS), dr hab. prof. UP Mirosław Michalik (UP), dr hab. prof. UG Stanisław Milewski (UG), dr hab. prof. US Barbara Ostapiuk (US).

Tematyka konferencji powstała w odpowiedzi na zgłaszane od lat zapotrzebowanie na standardy postępowania logopedycznego w przypadkach rozmaitych zaburzeń mowy. Logopedzi potrzebują nie tylko mocnej 
teorii i kunsztownego rzemiosła, ale również jasnych podstaw prawnych dla prowadzenia swojej praktyki.

Celem konferencji była prezentacja spójnego systemu postępowania logopedycznego na bazie ugruntowanej już wiedzy teoretycznej nad zaburzeniami mowy oraz wieloletniego doświadczenia praktycznego. Opracowywane modele procesu diagnostyczno-terapeutycznego mają być podstawą do określania form opieki logopedycznej, zwłaszcza w strukturach służby zdrowia i oświaty. Mają też być osnową treści programowych układanych na potrzeby dydaktyki w ośrodkach kształcących logopedów w całej Polsce.

Idea postępowania terapeutycznego $\mathrm{w}$ odniesieniu do rozmaitych zaburzeń prezentowana była $\mathrm{w}$ trakcie obrad plenarnych (21 referatów), natomiast eksplikacji niektórych etapów programu poświęcone były cykle zajęć warsztatowych ( 25 warsztatów). Poza częścią referatową i warsztatową zaprezentowano także sesję plakatową. 23 postery naukowe przybliżyły uczestnikom aktualny stan refleksji, kierunki rozwoju teorii, a także ciekawą kazuistykę, która zawsze stawia nowe problemy badawcze przed współczesną logopedią.

Konferencja miała charakter interdyscyplinarny, jej uczestnikami byli znawcy problematyki specjalizujący się w teorii i praktyce logopedycznej, a także w dyscyplinach pokrewnych (lekarze, pedagodzy) oraz studenci.

Czynny udział w konferencji wzięły 83 osoby, w tym wielu naukowców reprezentujących następujące ośrodki akademickie i instytuty naukowe: Akademia Ignatianum. Wydział Zamiejscowy Nauk Humanistycznych i Społecznych w Mysłowicach, Akademia Pedagogiki Specjalnej im. M. Grzegorzewskiej w Warszawie, Akademia Wychowania Fizycznego im. Jerzego Kukuczki w Katowicach, Collegium Medicum w Bydgoszczy, Katolicki Uniwersytet Lubelski Jana Pawła II w Lublinie, Uniwersytet Gdański, Uniwersytet Jana Kochanowskiego w Kielcach, Uniwersytet Łódzki, Uniwersytet Marii Curie-Skłodowskiej w Lublinie, Uniwersytet Medyczny w Lublinie, Uniwersytet Mikołaja Kopernika w Toruniu, Uniwersytet Pedagogiczny w Krakowie, Uniwersytet Przyrodniczo-Humanistyczny w Siedlcach, Uniwersytet Śląski w Katowicach, Uniwersytet Warmińsko-Mazurski w Olsztynie, Uniwersytet Warszawski oraz Instytut im. Marii Skłodowskiej-Curie w Gliwicach, Instytut Medycyny Pracy w Łodzi i Instytut Pomnik Centrum Zdrowia Dziecka w Warszawie.

Po powitaniu zebranych i występie Chóru Akademickiego UMCS im. Jadwigi Czerwińskiej rozpoczęły się obrady w czterech sesjach plenarnych. 
Pierwszy referat pt. „Logopedyczna koncepcja dostosowania podręczników szkolnych do specjalnych potrzeb edukacyjnych różnych grup uczniów z opóźnieniami rozwoju mowy i deficytami języka" wygłosiły Panie Kazimiera Krakowiak, Aleksandra Borowicz, Renata Kołodziejczyk (Katolicki Uniwersytet Lubelski Jana Pawła II w Lublinie). Autorki zwróciły uwagę, że ważnym sposobem udzielania wsparcia uczniom ze specjalnymi potrzebami edukacyjnymi jest opracowanie specjalistycznych podręczników, ściśle związanych z podręcznikami używanymi przez uczniów sprawnych, czyli podręczników zawierających te same zasadnicze treści, ale dostosowanych do specyficznych możliwości odbioru i rozumienia. Jako kolejni głos zabrali Stanisław Milewski, Katarzyna Kaczorowska-Bray (Uniwersytet Gdański). W swoim wystąpieniu podkreślili fakt, iż zmiany demograficzne polegające na starzeniu się społeczeństwa odczuwa coraz większa część populacji krajów rozwiniętych. Ważne jest zatem odpowiednie przygotowanie merytoryczne i praktyczne logopedów do pracy z osobami starszymi. Zbigniew Tarkowski (Uniwersytet Medyczny w Lublinie) w referacie poświęconym terapii psychogennych zaburzeń mowy, takich jak jąkanie i mutyzm przedstawił założenia i metody ich efektywnej terapii. Kolejny prelegent, Andrzej Czernikiewicz (Uniwersytet Marii Curie-Skłodowskiej w Lublinie), w swoim wystąpieniu dotyczącemu psychofarmakologii dla logopedów konstatował, że aktualnie największym problemem w grupie leków psychotropowych nie jest ich poziom skuteczności, ale to, na ile kreują one zjawisko współpracy. Jednocześnie badania nad mechanizmem działania leków psychotropowych pozwoliły na zrozumienie podłoża wielu zaburzeń psychicznych. Z kolei Alina Maciejewska, reprezentująca Uniwersytet Przyrodniczo-Humanistyczny w Siedlcach, w referacie pt. „Kompetencja logiczno-językowa a rozwój sprawności językowych" przedstawiła wyniki badań wskazujące na rolę naturalnej kompetencji logiczno-językowej w rozwoju sprawności językowych. Do jej oceny dość łatwo można wykorzystać umiejętność wnioskowania przez analogię o związkach formy i treści między jednostkami leksykalnymi i słowotwórczymi.

Drugą sesję plenarną otworzyła prelekcja Dawida Larysza i Agnieszki Rożek (Centrum Leczenia Zaburzeń OUN I Wspierania Rozwoju Dzieci „Kangur” w Katowicach): „Holistyczny model postępowania w zaburzeniach rozwoju mowy u dzieci z wadami twarzo-czaszkowymi na przykładzie izolowanych i zespołowych kraniosynostoz", w której Autorzy zaprezentowali aspekty neurologopedyczne, neurochirurgiczne, neuropsy- 
chologiczne oraz fizjoterapeutyczne leczenia wad twarzy i czaszki, składające się na nowoczesny interdyscyplinarny model postępowania diagnostyczno-terapeutycznego. Kolejne wystąpienie dotyczyło terapii logopedycznej, głównie stymulacji dotykowej, dziecka z mózgowym porażeniem dziecięcym. Renata Marciniak-Firadza z Uniwersytetu Łódzkiego omówiła metodę masażu w przypadku dyzartrii wiotkiej i spastycznej. Autorką masażu jest prof. Elena Archipowa. W trzecim w tej sesji referacie pt. „Specyfika oddziaływań logopedycznych w przypadku dzieci z SLI" Sofia Kamińska (Dzienny Ośrodek Psychiatrii i Zaburzeń Mowy dla Dzieci i Młodzieży we Wrocławiu) wyodrębniła niektóre strategie terapeutyczne wykorzystywane w leczeniu dzieci z SLI. W wystąpieniu dotyczącym kształtowania kompetencji komunikacyjnej w zabawie, Autorki: Ewa Bielecka-Nowakowska (Akademia Pedagogiki Specjalnej w Warszawie) i Anna Zając (Uniwersytet Jana Kochanowskiego w Kielcach) starały się uzasadnić, dlaczego strategie oparte na zabawie są najskuteczniejsze $\mathrm{w}$ procesie kształtowania kompetencji komunikacyjnej dziecka. W swoich rozważaniach wykorzystały pragmatyczne podstawy językoznawstwa oraz teorię umysłu. Następnie głos zabrały prelegentki z Uniwersytetetu Marii Curie-Skłodowskiej w Lublinie, Urszula Mirecka i Aneta Domagała, które, uznając, że standardy logopedyczne w zbyt ograniczonym zakresie uwzględniają zagadnienia zaburzeń języka pisanego, zaprezentowały możliwości włączenia tej problematyki do procesu diagnostyczno-terapeutycznego $\mathrm{w}$ patologii mowy. $\mathrm{W}$ referacie skoncentrowały się na terapeutycznych aspektach postępowania logopedycznego $\mathrm{w}$ pracy $\mathrm{z}$ osobami z zaburzeniami porozumiewania się $w$ mowie i piśmie. Jako ostatnia $w$ tej sesji wystąpiła z referatem Joanna Trzaskalik (Akademia Ignatianum, Wydział Zamiejscowy Nauk Humanistycznych i Społecznych w Mysłowicach), w którym podjęła próbę uzgodnienia terminologicznego, wychodząc z założenia, że jednoznaczność i precyzja używanych terminów służy profesjonalnej wymianie informacji, gwarantuje także jakość i skuteczność oddziaływań terapeutycznych.

Jako pierwszy w trzeciej sesji plenarnej wystąpił Tomasz Woźniak (Uniwersytet Marii Curie-Skłodowskiej w Lublinie). W referacie „Metody rytmizowania wypowiedzi w terapii osób jąkających się w świetle evidence based practice", rozważył skuteczność i ograniczenia metod terapii logopedycznej wykorzystujących metody rytmizowania wypowiedzi w świetle praktyki i najnowszych badań. Wnioski miały przede wszystkim charakter aplikacyjny. Następnie udzielono głosu Danucie Plucie Wojciechowskiej 
i Barbarze Sambor (Uniwersytet Śląski w Katowicach). W wystąpieniu poświęconemu zagadnieniu Inter-Speech Autorki podjęły nieopisany w dotychczasowej literaturze logopedycznej w Polsce i na świecie problem pozycji narządów mowy, w szczególności języka, podczas pauz w mówieniu u osób z zaburzeniami realizacji fonemów. Przedstawiły wyniki badań własnych, które dotyczą pozycji Inter-Speech u osób z dyslalią obwodową i osób z normatywną realizacją fonemów. Prezentacja Mirosława Michalika i Anny Cholewiak reprezentujących Uniwersytet Pedagogiczny w Krakowie dotyczyła wyników badań nad tempem wypowiedzi uczniów szkoły specjalnej dotkniętych oligofazją o podłożu niepełnosprawności intelektualnej w stopniu lekkim. Analizy wypowiedzi uczniów objęły wybrane ilościowe i jakościowe aspekty mowy. W referacie pt. „Ocena nosowości z zastosowaniem metody kształtowania wiązki akustycznej” Anita Lorenc i Daniel Król (Uniwersytet Warszawski) zaprezentowali stosowane współcześnie kliniczno-instrumentalne techniki oceny nosowości w mowie, zarówno na przykładach wymowy normatywnej, jak i zaburzonej. Z kolei Joanna Mąka podsumowała zależności pomiędzy centralnymi zaburzeniami procesów przetwarzania słuchowego (CAPD) a specyficznymi zaburzeniami rozwoju językowego (SLI). Zależności te zostały ujęte z perspektywy teorii funkcjonowania centralnego układu nerwowego. Jako ostatni w tej sesji głos zabrali Andrzej Senderski (Senso-Medical, Warszawa), Katarzyna Iwanicka-Pronicka (Instytut Pomnik Centrum Zdrowia Dziecka, Warszawa), Joanna Majak, Marzena Walkowiak (Instytut Medycyny Pracy, Łódź), Zenobia Bogdanowska (Poradnia Psychologiczno-Pedagogiczna nr 1 w Olsztynie) i Karolina Dajos (APD-Medical sp. z o.o., Warszawa). Celem wystąpienia pt. „Wartości normatywne przesiewowych testów wyższych funkcji słuchowych platformy diagnostyczno-terapeutycznej APD-Medical" było opracowanie i zaprezentowanie wartości referencyjnych dla przesiewowych testów ośrodkowych funkcji słuchowych zawartych na platformie diagnostycznej APD-Medical dla dzieci w wieku przedszkolnym i wczesnoszkolnym. Wykazano, że wiek istotnie wpływa na wyniki osiągane przez dzieci we wszystkich testach.

Ostatnią, czwartą sesję plenarną otworzył referat Barbary Kamińskiej z Uniwersytetu Gdańskiego. Autorka skonstatowała w nim, że konieczność spełnienia wymogów stawianych dziennikarzom sprawia, że cele pracy logopedy dotyczą nie tylko nauki (częściej - doskonalenia) poprawnej wymowy głosek, posługiwania się zdrowym, właściwym emisyjnie głosem, ale wyrazistego mówienia tzw. „radiowym” głosem, intonacją i tem- 
pem dostosowanym do poszczególnych rodzajów radiowych wypowiedzi. Olga Przybyla (Uniwersytet Śląski w Katowicach) w wystąpieniu „Poziomy organizacji przetwarzania informacji sensorycznych a rozwój sprawności językowych" przedstawiła wyniki badań wskazujące na związek poziomów organizacji przetwarzania informacji sensorycznych ze stanem rozwoju sprawności językowej dzieci z trudnościami w uczeniu się. Z kolei reprezentująca Uniwersytet Łódzki Ewa Gacka w referacie pt. „Podejście interakcyjne rodzic - dziecko w terapii opóźnień w rozwoju mowy" zwróciła uwagę na fakt, że bez względu na charakter opóźnienia w rozwoju mowy dziecko wymaga wczesnej interwencji logopedycznej. Jej celem jest diagnoza/rozpoznanie problemu, a także stymulacja rozwoju językowego. Ponieważ porozumiewanie się ma charakter interakcyjny, liczy się jakość i ilość kontaktów rodzic-dziecko. W wystąpieniu zaprezentowała Autorka strategie stymulacji rozwoju językowego, których podstawą jest nastawienie interakcyjne. Ostatnia z referentek, Anna Czernuszenko (Rehaklinik Bellikon, Szwajcaria) omówiła podstawowe postępowanie w dysfagii mające główne znaczenie dla zapobiegania jej śmiertelnym powikłaniom, podkreślając, że postępowanie w dysfagii nie jest skomplikowane, ale wymaga współdziałania wielu dyscyplin.

Każdej sesji towarzyszyło duże zainteresowanie, każdą zamykała dyskusja, niekiedy burzliwa, dotycząca poruszanych w niej tematów.

Jeśli chodzi o warsztaty naukowo-szkoleniowe, to uczestnikom konferencji zaproponowano ich sześć edycji.

W pierwszej edycji odbyły się następujące warsztaty: „Psychoedukacja” (prowadzący Andrzej Czernikiewicz, Uniwersytet Marii Curie-Skłodowskiej w Lublinie). W trakcie warsztatów przy użyciu techniki odgrywania ról zaprezentowane zostały możliwości psychoedukacji osób cierpiących na schizofrenię; "Gotowanie terapeutyczne” (prowadząca Agata Jędraszek, Nutricia Polska Sp. z o.o.). W ramach warsztatów omówione zostały konsystencje pokarmów przy zagęszczaniu preparatami zagęszczającymi, a także zaprezentowane praktyczne wskazówki dotyczące przygotowania jedzenia dla chorych z dysfagią oraz ich karmienia; „Warsztaty z emisji głosu - trening oddechowo-głosowo-dykcyjny w ruchu" (prowadzące Magdalena Zaorska i Magdalena Osowicka-Kondratowicz, Uniwersytet Warmińsko-Mazurski w Olsztynie). W treningu przedstawione zostały ćwiczenia, których priorytetem jest ukształtowanie nawyku energicznego, rytmicznego i płynnego oddechu dynamicznego. W treningu, obok ćwiczeń oddechowych w ruchu, pokazane zostały również ćwiczenia emisyj- 
ne, artykulacyjne i dykcyjne, których zadaniem jest korelacja szeroko rozumianego działania fizycznego z oddechem, głosem, słowem; „Metoda Neurofunkcjonalnej Reorganizacji Padovan w teorii i w praktyce logopedycznej” (prowadząca Aleksandra Listwoń, „Fundacja 21", Krosno). Warsztat poświęcony był prezentacji założeń Metody Neurofunkcjonalnej Reorganizacji Padovan na przykładzie zastosowania jej $\mathrm{w}$ terapii dziecka z trisomią 21. Prezentacja dotyczyła dynamiki nabywania przez dziecko kolejnych sprawności na przestrzeni dwóch lat, czyli od momentu rozpoczęcia stałej i systematycznej terapii z wykorzystaniem tej metody.

W edycji drugiej znalazły się warsztaty: "Zaburzenia połykania” (prowadząca Tatiana Lewicka, Nutricia Polska). Zostały na nim omówione m.in.: aspekty fizjologii i anatomicznych podstaw procesu połykania; fazy połykania; metody diagnozowania dysfagii ze szczególnym zwróceniem na poszczególne fazy; objawy dysfagii; metody terapii; powikłania dysfagii; leczenie żywieniowe; alternatywne dostępy do przewodu pokarmowego; przygotowanie posiłków; „Dysfunkcje oddychania i połykania w diagnozie i terapii logopedycznej" (prowadząca Izabela Malicka, International School of Krakow). W jego trakcie przedstawiono funkcję oddychania jako jedną z czynności prymarnych. Wskazano zależności pomiędzy oddychaniem, pozycją spoczynkową języka oraz połykaniem a zaburzeniem artykulacji. Podjęty temat został omówiony w aspekcie diagnozy oraz terapii logopedycznej; "Zaburzenia rezonansu w diagnozie i terapii logopedycznej" (prowadząca Danuta Pluta-Wojciechowska, Uniwersytet Śląski w Katowicach). Autorka przedstawiła zagadnienia dotyczące zaburzeń udziału rezonatora nosowego w tworzeniu dźwięków mowy z perspektywy logopedycznej i foniatrycznej. Zaprezentowała metody rozpoznawania zaburzeń rezonansu, a także sposoby ustalania ich przyczyn oraz określiła kierunki logopedycznego postępowania postdiagnostycznego $\mathrm{w}$ przypadku nosowania; "Stymulator Polimodalnej Percepcji Sensorycznej - polskie, innowacyjne urządzenie do prowadzenia wielozmysłowej terapii $\mathrm{w}$ grupach zaburzeń o podłożu sensorycznym" (prowadzący Bartłomiej Szylz, GNP Magnusson Aparatura Medyczna Sp. z o.o.). Podczas spotkania uczestnicy mogli zapoznać się z zasadą funkcjonowania systemu, założeniami terapii oraz prześledzić proces programowania terapii na urządzeniach demonstracyjnych.

W kolejnej, trzeciej edycji, uczestnicy mieli do wyboru następujące warsztaty: „Nowe metody diagnostyki i terapii centralnych zaburzeń słuchu" (prowadzące Zenobia Bogdanowska, Poradnia Psychologiczno-Peda- 
gogiczna nr 1 w Olsztynie i Olga Przybyla, Uniwersytet Śląski w Katowicach). Warsztat dotyczył następujących zagadnień: centralne zaburzenia słuchu: definicja, epidemiologia, patomechanizmy i podtypy kliniczne; diagnostyka - część teoretyczna - omówienie testów oceniających wyższe funkcje słuchowe oraz praktyczna prezentacja narzędzia do diagnozy CAPD - Platformy APD-Medical; postępowanie terapeutyczne: podstawy teoretyczne poprawy funkcji słuchowych oraz prezentacja aktywnego treningu słuchowego Neuroflow; „Programowanie języka polskiego u dzieci dwujęzycznych" (prowadząca Urszula Ciszewska-Psujek, Uniwersytet Marii Curie-Skłodowskiej w Lublinie). Niniejsze warsztaty były przeglądem metod i technik używanych w uczeniu języka polskiego jako obcego dzieci obcokrajowców lub polskich dzieci dwujęzycznych w wieku przedszkolnym i wczesnoszkolnym, które mogą być także wykorzystywane w terapii dzieci z opóźnionym rozwojem mowy. Podczas spotkania zaprezentowano także opracowane przez autorkę przykładowe ćwiczenia gramatyczne służące panowaniu fleksji nominalnej i werbalnej; „Terapia Pozycji Oralnej Talk Tools" (prowadzący Piotr Jaworski, PJtherapeutic Piotr Jaworski). Program warsztatów objął m.in. następujące zagadnienia: OPT i inne programy terapii oparte na modelu fizjoterapii; podstawy teoretyczne OPT, definicja planu motorycznego; niezbędne warunki dla poprawy wyrazistości mowy; cele OPT; model diagnozy z uwzględnieniem karmienia; narzędzia terapii i diagnozy: m.in. bloczki żuchwowe, hierarchia flecików, narzędzia do pionizacji i lateralizacji języka w hierarchii strukturalno-funkcjonalnej, model: żuchwa-wargi-język; karmienie jako element programu OPT; „Rozwijanie komunikacji na poziomie przedsymbolicznym - podstawa terapii logopedycznej dziecka z autyzmem" (prowadząca Magdalena Tarnawska, Poradnia Psychologiczno-Pedagogiczna, Poradnia Specjalistyczna dla Osób z Autyzmem w Świdniku). W trakcie spotkania zaprezentowano strategię pracy z dzieckiem ze spektrum autyzmu, która oparta jest na doświadczeniach zawodowych prowadzącej. Omówiono specyfikę rozwoju komunikacji osób z autyzmem, następnie przedstawiono techniki terapeutyczne rozwijające umiejętności komunikacyjne istotne dla pojawienia się komunikacji symbolicznej.

W edycji czwartej przeprowadzono warsztaty: „Innowacyjne metody neurorehabilitacji w terapii funkcji językowych i poznawczych" (prowadzące Bożena Duda, Katarzyna Broniec-Siekaniec, Dorota Pikuła, Górnośląskie Centrum Rehabilitacji „REPTY” w Tarnowskich Górach). Zaprezentowano na nim innowacyjne metody neurorehabilitacji: „System C-Eye, 
Rehacom i Biofeedback", wykorzystywane do diagnozy i terapii pacjentów z uszkodzeniem mózgu, przebywających na leczeniu w GCR "Repty"; "Jak tworzyć teksty łatwe do czytania? Zasady tworzenia oraz modyfikacji tekstów dostosowanych do możliwości percepcyjnych osób o specjalnych potrzebach komunikacyjnych" (prowadzące Renata Kołodziejczyk, Aleksandra Borowicz, Katolicki Uniwersytet Lubelski im. Jana Pawła II w Lublinie). Celem warsztatów było zapoznanie uczestników z zasadami tworzenia lub modyfikacji tekstów, aby ułatwić ich rozumienie osobom z zaburzeniami komunikacji językowej: z uszkodzeniami słuchu, afazją, autyzmem, lekką niepełnosprawnością intelektualną oraz osobom o specjalnych potrzebach komunikacyjnych: cudzoziemcom, dzieciom polskim powracającym z emigracji itp. Dostosowanie może dotyczyć układu logicznego tekstu, treści, słownictwa, struktur składniowych, a także postaci graficznej tekstu. Uczestnicy warsztatów mieli okazję wykorzystać w praktyce poznane zasady, tworząc samodzielnie teksty łatwe do czytania oraz podejmując się modyfikacji tekstów trudnych; "Terapia mowy osób z ASD w oparciu o werbalne zachowania sprawcze" (prowadzący Wojciech Lipski, Uniwersytet Marii Curie-Skłodowskiej w Lublinie). Warsztat poświęcony był zastosowaniu teorii dotyczącej werbalnych zachowań sprawczych (ang. verbal operant) według B.F. Skinnera, w procesie terapii osób z ASD. Werbalne zachowania sprawcze mogą stanowić podstawę do przeprowadzenie diagnozy o dużym wymiarze funkcjonalnym i budowania wyprofilowanego, pod kątem umiejętności komunikacyjnych konkretnego dziecka, programu terapii. Rozbudowywanie repertuaru zachowań werbalnych umożliwia osobie z ASD rozwinięcie zdolności komunikacyjnych; „Wykorzystanie środowiska naturalnego w terapii logopedycznej” (prowadzący Aleksandra Matyjasek i Rafał Matyjasek, Uniwersytet Marii Curie-Skłodowskiej w Lublinie). Celem warsztatów było przedstawienie znaczenia hortiterapii, omówienie zasad projektowania ogrodów sensorycznych z uwzględnieniem roślinności i elementów małej architektury oraz zaproponowanie konkretnych oddziaływań terapeutycznych wspierających funkcje poznawcze i komunikacyjne $\mathrm{w}$ oparciu o autorskie koncepcje projektowe.

W piątej edycji znalazły się warsztaty: „Kształtowanie umiejętności społecznych i komunikacyjnych u dzieci i młodzieży z zaburzeniami ze spektrum autyzmu" (prowadząca Aleksandra Matyjasek, Uniwersytet Marii Curie-Skłodowskiej w Lublinie). Uczestnicy warsztatów nauczyli się formułować cele terapeutyczne, stosować systemy motywacyjne, a także 
poznali techniki wykorzystywane w pracy terapeutycznej; „Terapia ręki oraz Zintegrowany trening pisania SIhand ${ }^{\circledR}$ jako forma wspomagania rozwoju dziecka" (prowadząca Agnieszka Rosa, Orticus Centrum Terapii Widzenia i Rozwoju). W trakcie warsztatów omówiono zestaw optymalnie dobranych ćwiczeń $\mathrm{w}$ terapii ręki oraz $\mathrm{w}$ zintegrowanym treningu pisania SIhand ${ }^{\circledR}$ m.in.: rozwijanie prawidłowych wzorców ruchu z zakresu dużej oraz małej motoryki, rozwijanie prawidłowego wzorca ruchu czynności grafomotorycznych, korekcję nieprawidłowego chwytu pisarskiego; „Kształtowanie sprawności prozodycznych" (prowadząca Marta Wysocka, Uniwersytet Marii Curie-Skłodowskiej w Lublinie). Celem warsztatów było zapoznanie uczestników z technikami i metodami służącymi usprawnianiu percepcji i realizacji zjawisk prozodycznych, które mogą mieć zastosowanie $\mathrm{w}$ terapii zaburzeń mowy, $\mathrm{w}$ logopedii artystycznej oraz $\mathrm{w}$ procesie stymulacji rozwoju mowy dziecka.

W ostatniej, szóstej edycji uczestnicy konferencji mogli wybierać wśród następujących warsztatów: Metody postępowania neurologopedycznego $\mathrm{w}$ dysfagii neurogennej z wykorzystaniem aparatów VocaSTIM i IOPI (prowadzące Ewelina Abramowicz-Pakuła i Grażyna Kubacka, Górnośląskie Centrum Rehabilitacji „REPTY” w Tarnowskich Górach). Warsztat miał na celu przedstawienie różnorodnych metod $w$ terapii dysfagii stosowanych w zależności od miejsca uszkodzenia i stanu chorego. Przedstawione zostały metody adaptacyjne, kompensacyjne, restytucyjne, sposoby stymulacji, także przy użyciu aparatu VocaSTIM; Program 60 kroków w terapii zaburzeń mowy - poziom III (prowadząca Katarzyna Ita Bieńkowska, Akademia Pedagogiki Specjalnej im. M. Grzegorzewskiej w Warszawie, Stowarzyszenie Rodziców i Przyjaciół Dzieci z Wadą Słuchu w Krośnie). Autorka warsztatów zapragnęła podzielić się swoimi doświadczeniami i przemyśleniami związanymi z pracą nad poziomem III językowym. $W$ trakcie warsztatów wraz $\mathrm{z}$ uczestnikami przedyskutowane zostały zasady poszerzania zasobu leksykalnego, paradygmatycznego i asocjacyjnego oraz budowania składni zarówno w naturalnym dialogu, jak i podczas planowanych ćwiczeń $\mathrm{w}$ zgodzie $\mathrm{z}$ metodą audytywno-werbalną; Praca z oddechem w rehabilitacji głosu (prowadząca Barbara Sambor, PWST im. L. Solskiego w Krakowie, Uniwersytet Śląski w Katowicach). Celem warsztatów było zapoznanie uczestników z problemami oddechowymi u dzieci i dorosłych z różnymi odmianami dysfonii. W trakcie warsztatów zostały przeanalizowane różne metody pracy z oddechem pod kątem ich skuteczności i zgodności z najnowszą wiedzą z dziedziny 
rehabilitacji głosu. Uczestnicy poznali skuteczne techniki przywracania fizjologicznego oddychania oraz prawidłowej koordynacji oddechowo-fonacyjno-artykulacyjnej podczas prowadzenia terapii głosu; Terapia logopedyczna dzieci z padaczką (prowadząca Magdalena Kozłowska, Uniwersytet Marii Curie-Skłodowskiej w Lublinie). W trakcie warsztatów omówione zostały m.in. następujące zagadnienia: padaczka jako najczęstsze zaburzenie neurologiczne wieku rozwojowego oraz zaburzenia rozwojowe w padaczce: zaburzenia językowe, komunikacyjne, poznawcze, ruchowe, emocjonalne; diagnozowanie zaburzeń, programowanie terapii i standard postępowania logopedycznego w nurcie metod integracyjnych: stymulowanie rozwoju psychomotorycznego (założenia metod psychomotorycznych na przykładzie terapii metodą Procus i Block); eliminowanie niedojrzałości neuromotorycznej poprzez terapię ruchową nakierowaną na poziom odruchów pierwotnych; stymulowanie rozwoju i integracji zmysłów u dzieci z padaczką; Integracja sensoryczna jako metoda wspierająca terapię logopedyczną (prowadząca Sylwia Filipczak, Uniwersytet Marii Curie-Skłodowskiej w Lublinie). Warsztat miał na celu zaprezentowanie metody integracji sensorycznej i zasady zastosowania jej elementów w terapii logopedycznej; "Uczę się mówić, wymawiać, opowiadać” - zastosowanie książki edukacyjnej w profilaktyce i terapii zaburzeń mowy dziecka (prowadząca Marta Galewska-Kustra, Akademia Pedagogiki Specjalnej im. Marii Grzegorzewskiej w Warszawie). W trakcie warsztatów przedstawiono możliwości świadomego wspierania rozwijającej się mowy dziecka z wykorzystaniem edukacyjnej literatury dla dzieci z serii „Uczę się: mówić, wymawiać opowiadać".

Warto podkreślić, że wszystkie warsztaty dzięki doświadczeniu specjalistów prowadzących szkolenia, były dla uczestników źródłem bardzo cennych i praktycznych informacji.

W trakcie konferencji zaprezentowano też postery naukowe. Wśród plakatów znalazły się następujące prace, których autorami byli: Kamila Bigos (Uniwersytet Marii Curie-Skłodowskiej w Lublinie), "Zaburzenia artykulacji w mózgowym porażeniu dziecięcym. Studium przypadku". Autorka przedstawiła studium przypadku siedmioletniego chłopca z mózgowym porażeniem dziecięcym. Przy pomocy technik i narzędzi badawczych dokonała oceny budowy i sprawności narządów mowy, słuchu fonematycznego oraz artykulacji. Wskazała również cele postępowania terapeutycznego; Kamila Bigos, Karolina Gruszka (Uniwersytet Marii Curie-Skłodowskiej w Lublinie), „Niemowlę u logopedy. Stymulacja rozwoju 
psychoruchowego dziecka w pierwszym roku życia". W posterze zwrócono uwagę na to, jak ważny jest prawidłowy rozwój ruchowy i rozwój funkcji poznawczych w pierwszym roku życia dziecka; Urszula CiszewskaPsujek (Uniwersytet Marii Curie-Skłodowskiej w Lublinie), "Czy alkoholikom potrzebna jest terapia logopedyczna?". Autorka podkreśla, że toksyczne oddziaływanie alkoholu na ośrodkowy układ nerwowy prowadzi do trwałego zmniejszenia się liczby i rozmiaru neuronów i połączeń neuronalnych, a w konsekwencji do zaburzeń poznawczych, w tym funkcji wykonawczych i pamięci oraz zaburzeń przetwarzania informacji emocjonalnych. Osobom uzależnionym od alkoholu może przydać się logopeda, który wskaże drogę, jak za pomocą języka stymulować działanie mózgu; Katarzyna Cygan (Uniwersytet Marii Curie-Skłodowskiej w Lublinie), „Spójność obrazów narracyjnych u dzieci z padaczką". Istotą tego plakatu jest ukazanie, w jaki sposób dzieci z padaczką realizują obrazy narracyjne w tekstach tworzonych na podstawie historyjek obrazkowych i zadanych tematów; Ewa Dzięcioł-Chlibiuk (Uniwersytet Przyrodniczo-Humanistyczny w Siedlcach), "Językowe wykładniki metafor w wypowiedziach studentów z niepełnosprawnością słuchową" - na podstawie zebranych od studentów z niepełnosprawnością słuchową ankiet, Autorka stara się odpowiedzieć na pytania: $\mathrm{w}$ jaki sposób osoby niedosłyszące rozumieją formy przenośne: potoczne metafory, związki frazeologiczne i przysłowia, czy adekwatnie odnoszą je do konkretnej sytuacji, czy posługują się nimi $\mathrm{w}$ codziennych interakcjach. Co stanowi największy problem w przyswojeniu metaforycznych znaczeń. Czy w systemie pojęć u osób z dysfunkcją słuchu istnieją wyrażenia przenośne i $\mathrm{w}$ jaki sposób są przez nie postrzegane i interpretowane. W jaki sposób starają się wyjaśniać związki, których nie znają; Karolina Gruszka (Uniwersytet Marii Curie-Skłodowskiej w Lublinie), „Sprawności językowe i komunikacyjne dziecka z mózgowym porażeniem dziecięcym". Celem prezentacji jest opis i analiza sprawności językowych i komunikacyjnych dziecka z mózgowym porażeniem dziecięcym. Wyniki badań uzyskane zostały w oparciu o standard logopedycznego postępowania diagnostycznego. Zwrócono też uwagę na postępowanie terapeutyczne; Ewa Hrycyna (Uniwersytet Warmińsko-Mazurski w Olsztynie), "Zaburzenia semantyczne i pragmatyczne u dzieci w wieku przedszkolnym - propozycje oddziaływań terapeutycznych". Plakat przedstawiał temat wybranych propozycji oddziaływań terapeutycznych $\mathrm{w}$ przypadku zaburzeń semantyczno-pragmatycznych $\mathrm{u}$ dzieci $\mathrm{w}$ wieku przedszkolnym. Podkreślał ważność podejmowanego tematu w kontekście 
codziennego funkcjonowania dziecka w różnych grupach społecznych (rodzina, rówieśnicy, grupa przedszkolna); Aleksandra JastrzębowskaJasińska (Gabinet Mówię Dobrze w Warszawie), „Metody terapii jąkania u młodzieży i osób dorosłych na podstawie studiów przypadków". Autorka zaprezentowała trzy studia przypadków, które zobrazowały sposób prowadzenia terapii jąkania, a także pokazały, że zastosowane metody (jąkania bardziej płynnego lub mówienia bardziej płynnego) mogą być skuteczne w leczeniu jąkania u pacjentów dorosłych i u młodzieży; Olga Jauer-Niworowska, Anna Lis (Uniwersytet Warszawski), „Terapia logopedyczna osób z dyzartrią poudarową (z uwzględnieniem zaburzeń połykania)". Plakat dotyczył kompleksowej terapii logopedycznej osób z dyzartrią poudarową o zróżnicowanych objawach zależnych od lokalizacji udaru. Autorki zaprezentowały na nim także zasady terapii pacjentów z zaburzeniami połykania towarzyszącymi dyzartrii; Aldona Kocyła-Łukasiewicz (Uniwersytet Przyrodniczo-Humanistyczny w Siedlcach), "Centralne Zaburzenia Przetwarzania Słuchowego jako jedna z przyczyn zaburzeń komunikacji językowej". Autorka zaznaczyła, że właściwie postawiona diagnoza pozwala zaplanować i ukierunkować pracę terapeutyczną z dzieckiem. Odpowiednio prowadzona terapia centralnych zaburzeń przetwarzania słuchowego poprawia sprawność komunikacyjną dziecka, jego funkcjonowanie w szkole. Możliwości terapeutyczne są duże: od standardowych metod pracy terapeutycznej po nowoczesne metody rehabilitacji: treningi słuchowe metodą Tomatisa, Johansena czy Warnkego; Sylwia Krupa (Uniwersytet Marii Curie-Skłodowskiej w Lublinie), „Sprawności dialogowe osób z uszkodzeniami płatów czołowych". Tematem posteru były sprawności dialogowe osób z uszkodzeniami płatów czołowych. Ocenę sprawności dialogowej, opartą o zgromadzony materiał badawczy, Autorka rozpatrzyła trójaspektowo: pod względem struktury dialogu, spójności występujących w nim reakcji, a także długości wypowiedzi. Rezultatem analizy było zestawienie najbardziej charakterystycznych cech sprawności dialogowej omawianych pacjentów; Natalia Kryszak (Uniwersytet Marii Curie-Skłodowskiej w Lublinie), „Trudności w czytaniu i pisaniu u bliźniąt z alalią motoryczną". Autorka wykazała związek między sprzężonymi problemami rozwojowymi, w tym alalią, a trudnościami w czytaniu i pisaniu; Marlena Kurowska (Uniwersytet Warszawski), „Sposoby aktualizowania prawidłowej struktury brzmieniowo-artykulacyjno-gramatycznej wyrazów u dzieci z zaburzeniami w rozwoju mowy i języka uwarunkowanymi korowo". Na plakacie Autorka przedstawiła grupy ćwi- 
czeń i technik pozwalające na łatwiejsze i szybsze przywoływanie oczekiwanej $\mathrm{w}$ danym kontekście formy wyrazu: znaczeniowej, brzmieniowo-artykulacyjnej oraz gramatycznej; Magdalena Kwaterkiewicz (Uniwersytet Marii Curie-Skłodowskiej), „Wpływ ćwiczeń muzycznych i muzycznoruchowych na rozwój kompetencji prozodycznych dzieci 5-, 6-letnich”. W posterze naukowym Autorka zaprezentowała wyniki badań własnych dotyczących wpływu ćwiczeń muzycznych i muzyczno-ruchowych na rozwój kompetencji prozodycznych dzieci pięcio-sześcioletnich, u których system fonetyczno-fonologiczny kończy swój dynamiczny rozwój; Hanna Owczarzak, Lidia Nawrocka, Anna Sinkiewicz (Collegium Medicum w Bydgoszczy, Uniwersytet Mikołaja Kopernika w Toruniu), „Rehabilitacja głosu i mowy u pacjenta po usunięciu krtani i przełyku". Przedstawiono na plakacie przebieg rehabilitacji logopedyczno-foniatrycznej 78-letniego pacjenta po całkowitym usunięciu krtani i przełyku z rekonstrukcją za pomocą transpozycji żołądka. W programie rehabilitacji wykorzystano doświadczenie oparte na nauce mowy przełykowej; Hanna Owczarzak, Hanna Mackiewicz-Nartowicz, Adam Maciejewski, Krzysztof Oleś, Cezary Szymczak, Łukasz Krakowczyk, Maciej Grajek, Anna Sinkiewicz (Collegium Medicum w Bydgoszczy, Uniwersytet Mikołaja Kopernika w Toruniu, Instytut im. M. Skłdowskiej-Curie w Gliwicach), "Rehabilitacja głosu i połykania u pacjenta po przeszczepie krtani". Na plakacie przedstawiono przebieg rehabilitacji logopedyczno-foniatrycznej 39-letniego pacjenta po transplantacji krtani. Do rehabilitacji włączono ćwiczenia toru oddechowego, aparatu artykulacyjnego oraz ćwiczenia fonacyjne, wykorzystując elementy metody wokalistyczno-fonetycznej. Równolegle wprowadzono ćwiczenia połykania; Jolanta Panasiuk (Uniwersytet Marii Curie-Skłodowskiej w Lublinie), „Procedury diagnostyczno-terapeutyczne w zespole zamknięcia". W formie plakatu przedstawiono zagadnienia potrzeby rehabilitacji neurologopedycznej osób z zespołem zamknięcia. Potrzeba ta wiąże się zarówno z poprawą standardów leczenia klinicznego, jak też z rozpowszechnieniem wiedzy o samym zespole i sytuacji życiowej osób nim dotkniętych; Jolanta Panasiuk (Uniwersytet Marii Curie-Skłodowskiej w Lublinie), Maria M. Kaczyńska-Haładyj (Szpital Neuropsychiatryczny w Lublinie), „Rozwój dziecka z zespołem Dravet. Dezintegracja - neuroplastyczność - neurokompensacja". W pracy zaprezentowano wieloaspektową ocenę zaburzeń neurorozwojowych u sześcioletniego chłopca z zespołem Dravet $\mathrm{z}$ uwzględnieniem zmian wynikających $\mathrm{z}$ przebiegu choroby i jej skutków dla motorycznego, emocjonalno-społecznego, po- 
znawczego i językowo-komunikacyjnego funkcjonowania. Wielospecjalistyczna ocena dziecka, weryfikowana w kolejnych fazach przebiegu choroby, pozwala planować optymalną, efektywną terapię i rehabilitację opisywanego dziecka; Jolanta Panasiuk (Uniwersytet Marii Curie-Skłodowskiej w Lublinie), Maria M. Kaczyńska-Haładyj (Szpital Neuropsychiatryczny w Lublinie), „Dysocjacja czy neurodegeneracja. Problemy diagnozy, leczenia i rehabilitacji". Autorki pokazały, że diagnoza zaburzeń degeneracyjnych musi przebiegać wieloetapowo i kompleksowo. Ze względu na dynamiczny charakter zmian otępiennych należy zwrócić uwagę na objawy prodromalne poprzedzające występowanie objawów demencji wieku rozwojowego. Oddziaływania rehabilitacyjne są zróżnicowane na poszczególnych etapach choroby i zdrowienia. W wyniku oddziaływań rehabilitacyjno-edukacyjnych może nastąpić poprawa $\mathrm{w}$ zakresie funkcjonowania poprawczego; Jolanta Panasiuk (Uniwersytet Marii Curie-Skłodowskiej w Lublinie), Maria M. Kaczyńska-Haładyj (Szpital Neuropsychiatryczny w Lublinie), "Zaburzenia neurorozwojowe w padaczce. Dynamika - leczenie - terapia". W pracy przedstawiono dynamikę zaburzeń neurorozwojowych w przebiegu ciężkiego przypadku padaczki objawowej ze stanami padaczkowymi u siedmioletniego chłopca oraz wpływ wielospecjalistycznej terapii na ustąpienie objawów padaczki i znaczną poprawę $\mathrm{w}$ funkcjonowaniu motorycznym, społeczno-emocjonalnym i poznawczo-językowym; Ewa Wolańska (Uniwersytet Warszawski), „Nowe formy rehabilitacji neurologopedycznej jako odpowiedź na nowe formy farmakoterapii w chorobie Alzheimera". Autorka zaprezentowała plakat opiniotwórczy dotyczący nowych form rehabilitacji neurologopedycznej jako odpowiedzi na nowe formy farmakoterapii stosowanej $\mathrm{w}$ chorobie Alzheimera. Celem takiej rehabilitacji stanie się umożliwienie pacjentom powrotu do względnej samodzielności poprzez pobudzanie naturalnej odbudowy uszkodzonych funkcji oraz uczenie pacjentów sposobów kompensacji tych deficytów, które okażą się trwałe; Marta Wysocka (Uniwersytet Marii Curie-Skłodowskiej w Lublinie), „Prozodia emocjonalna w percepcji dzieci z uszkodzonym narządem słuchu i dzieci słyszących". Plakat prezentował wyniki badań własnych nad odbiorem wyrażonych prozodycznie emocji przez dzieci z prelingwalnym uszkodzeniem narządu słuchu oraz przez dzieci słyszące. Sugerowały one, że pomimo uzyskanej dzięki zastosowani protez słuchowych możliwości odbioru sygnału mowy, dzieci z uszkodzonym narządem słuchu mają duże trudności w percepcji prozodii emocjonalnej; Anna Zwierzchowska (Akademia Wychowania Fizycznego im. Jerzego 
Kukuczki w Katowicach), Katarzyna Ita Bieńkowska (Akademia Pedagogiki Specjalnej im. M. Grzegorzewskiej w Warszawie, Stowarzyszenie Rodziców i Przyjaciół Dzieci z Wadą Słuchu w Krośnie), "Ćwiczenia kompensujące zaburzenia czucia, kontroli ciała i równowagi dla dzieci z wadą słuchu". Na plakacie przedstawiono kilkanaście prostych ćwiczeń nie tylko aktywizujących małą i dużą motorykę, ale też wpływających na efekty interdyscyplinarnych oddziaływań, mających na celu kompensację deficytów rozwojowych spowodowanych wadą słuchu u dzieci.

Konferencja bez wątpienia spełniła swój cel - stała się bowiem dla uczestników forum dyskusji, wymiany poglądów, doświadczeń, umiejętności. Przyczyniła się też do zacieśniania współpracy naukowej różnych ośrodków. 